\title{
Worldwide news
} and comment

\section{THAILAND: PHILIP MORRIS MOVES TO BLOCK NEW LAW}

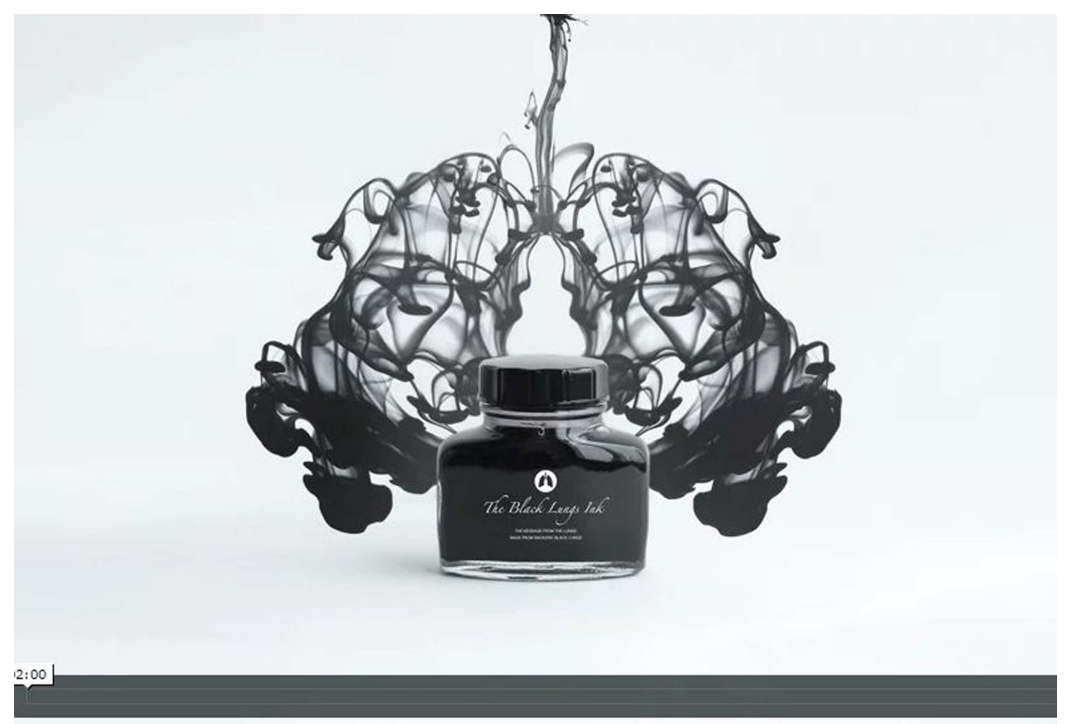

\section{The Message from the Lungs (Thai Health Promotion Foundation)}

Message From The Lungs. Source: https://vimeo.com/126220314

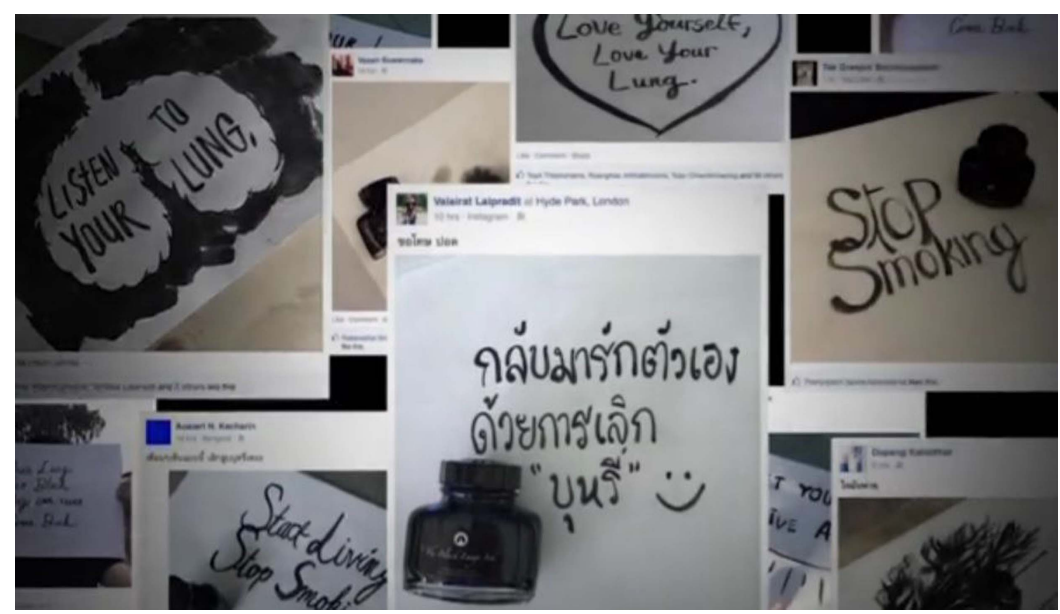

Artwork created from 'Message From The Lungs' ink

ASH Thailand has alleged that Philip Morris International has written to the country's Ministry of Public Health in an effort to prevent a new law on tobacco

All articles written by Marita Hefler unless otherwise attributed. Ideas and items for News Analysis should be sent to: marita.hefler@menzies.edu.au control being passed. The law was due to be fast-tracked earlier this year following delays the public health minister reportedly blamed on the agriculture and finance ministries. It has since been further delayed amidst accusations of tobacco industry lobbying.

If passed, the new law will increase the legal age for purchasing cigarettes from 18 to 20 , tighten advertising and marketing bans-including on social media-and prohibit tobacco industry corporate social responsibility initiatives. According to ASH Thailand Secretary General Prakit Watheesathokkij, PMI's letter argued that Thailand's existing tobacco control laws are sufficient for educating people about the harms of smoking and preventing uptake.

The tobacco industry is up against a formidable and very creative foe in Thailand, which has a long history of strong tobacco control action, with both ASH Thailand and the Thai Health Promotion Foundation providing leadership in the Southeast Asian region. The Thai Health Promotion Foundation's latest campaign uses dead smokers' lungs to send a direct message to smokers-literally.

The Message From The Lungs opens with blank ink dispersing into water and a paint brush making a bold black stroke on canvas, with the words: "This is not ordinary ink. Because it was the life's work of a man. A man who spent 50 years of his life to make every drop of it...by smoking every day".

It goes on to explain how Thai Health teamed up with the Faculty of Medicine at Chulalongkorn University to make ink extracted from the tar in lungs donated by smokers. The ink was then bottled and used to create artwork for ads. Samples were also distributed in public spaces as part of exhibitions to convince people to quit.

According to Thai Health, the campaign has resulted in a five-fold increase in quit smoking program participation. You can read more and view the ad at http://blogs.bmj.com/tc/2015/05/27/thisartistic-ad-from-thailand-will-make-youthink-and-gasp/

\section{MALAYSIA: COMMITTING TO AN ENDGAME DATE}

The Malaysian government has recently joined a growing number of countries setting a target date for smoking prevalence to fall to below $5 \%$.

The Kuala Lumpur International Nicotine Addiction Conference, hosted by the University of Malaya on April 2224th and launched by the Minister for Health, was held as part of Malaysia's commitment to Articles of 12 and 14 of the FCTC. It was attended by 160 participants, mainly from Malaysia and Southeast Asia, as well as limited participation by countries outside the region, including Nigeria.

During the conference, the Minister announced a government target for smoking prevalence to fall to $15 \%$ by 2025 and $5 \%$ or lower by 2045 . The point was made by one speaker that 2045 is less than ambitious given an estimated 
20,000 Malaysians die from tobaccoattributable disease per year. A very long 30 years away, it is five years beyond the global target of 2040 recently proposed in a Lancet editorial by Professor Robert Beaglehole and colleagues, and far later than the 2025 date set by New Zealand.

The Minister also announced additional funding for expanding smoking cessation clinics to add to the current 450 clinics nationwide, and the establishment of a telephone Quitline service. However, research presented at the conference suggested far more needed to be done to roll out basic cessation support training to all health workers as the current workforce is undertrained, under-informed, lacking confidence and not providing the level of smoking cessation services required to reach the numbers of people who need support.

More immediate gains are unlikely to be won unless a stronger stance is taken by the government with the tobacco industry. A recent study published in Tobacco Control, SEATCA Tobacco Industry Interference Index: a tool for measuring implementation of the WHO Framework Convention on Tobacco Control Article 5.3, indicated the industry is still very influential in the Southeast Asian region.

While more needs to be done, there are other encouraging signs. The Malaysian government is incentivising tobacco growers to shift to alternate crops, such as kenaf (hibiscus cannabinus) from which fibre can be used to strengthen building products. Malaysia also appears to be standing firm in its resolve that tobacco be carved out of the provisions of the Trans Pacific Partnership Agreement (TPPA), a major free trade agreement that proposes to constrain signatory nations' sovereign right to control tobacco and other commodities with public health impacts, such as alcohol and pharmaceuticals.

The country's stance against TPPA provisions would protect governments' ability to enact FCTC provisions and has been praised by regional health groups. Dr Mary Assunta, senior policy advisor to the Southeast Asia Tobacco Control Alliance, has said: "Excluding tobacco from investment agreements will be a phenomenal change in how tobacco should be viewed - as a harmful product that kills its customers and should not be accorded the same privileges given to other products”.

\section{Amer Siddiq Amer Nordin}

Farizah Mohd Hairi University Malaya Centre of Addiction Sciences, Malaysia amersiddiq@um.edu.my
Christopher Bullen

National Institute for Health Innovation, New Zealand

\section{WORLD: MARLBORO \& FERRARI CONTINUE F1 PARTNERSHIP}

In May 2015 the Scuderia Ferrari Formula One (F1) team and Philip Morris International (PMI) announced they had renewed their sponsorship agreement until 2018. Although tobacco advertising was banned in the sport at the end of the 2006 season, is believed that the agreement (currently estimated at $\$ 160$ million per year) was quietly renewed at a 2014 F1 board meeting in Italy, over a year before the public announcement.

Previously, it was rumoured that the partnership might end after the 20112015 agreement. In 2013, the longrunning PMI/Ferrari winter "Wrooom" skiing event at the Madonna di Campiglio resort in Italy was cancelled due to the increasing costs of staging it. International media were invited to this event which featured PMI representatives, the Scuderia Ferrari drivers and Ducati MotoGP riders (also sponsored by PMI).

Ferrari's current F1 Team Principal Maurizio Arrivabene was, until November 2014, PMI's Vice President of Consumer Channel Strategy and Event Marketing. Arrivabene has also sat on the F1 Commission since 2010 as a representative for all of the sport's sponsors. The links between Scuderia Ferrari and PMI run much deeper than simply having an ex-PMI marketing employee as team principal: Sergio Marchionne, current CEO of Ferrari's parent company Fiat S.p.A, is on PMI's Board of Directors. The world's richest man, Carlos Slim, also sat on PMI's Board of Directors until May 2015, and his telecommunications company, Claro, became a sponsor of Scuderia Ferrari in 2014. It was suggested in the media that one of Slim's companies could fill the void should PMI withdraw its sponsorship at the end of 2015.

From 2007-2011 the team's official name, "Scuderia Ferrari Marlboro" was used in press conferences, interviews, and in the print press. The team even ran with Marlboro branding at three Grand Prix in 2007: Bahrain, Monaco and China. A red, white and black barcode design was displayed in the same positions for other races until May 2010, when it was dropped from the cars after criticism that it was subliminally advertising the cigarette brand. The barcode design remained on the drivers' and team members' gear for the remainder of the season.
In July 2010 the team launched a new logo for the 2011 season, with many observing that it closely resembled the Marlboro chevron. This design is still in use by the team, and has even crept into official Formula One video game titles. In July 2011, Ferrari announced that they were dropping 'Marlboro' from its official team title, whilst also confirming that they had renewed their partnership with PMI until 2015.

At the recent 2015 Monaco Grand Prix, Marlboro advertising boards (external to the track) included images of Scuderia Ferrari's four-time Formula One Drivers Champion Sebastian Vettel. The advertisements include statements such as "Red is Inspiration", "Red is Action" and "Red is Innovation." Each advertisement also incorporates the "Be Marlboro" slogan. It was reported that when Vettel was asked about the images in Monaco, he stated: "I think everybody already knows who our biggest sponsor is".

F1's governing body, the Federation Internationale de l'Automobile first announced in 2002 that tobacco sponsorship of international motorsport would cease by the end of the 2006 season. Despite this, thirteen years later, there is still a very strong relationship between Scuderia Ferrari and PMI.

\section{John Baker \\ Central Victorian Primary Care Partnership, Australia ihpp@centralvicpcp.com.au}

\section{WORLD: BE MARLBORO, BE...} INVISIBLE?

Marlboro's sponsorship of the F1 Scuderia Ferrari team has been described as 'one of the quietest in sport'. Now, it seems PMI is taking a similarly coy approach to the global marketing campaign 'Be Marlboro'.

As reported in the May and November 2014 issues of News Analysis, the advertising campaign, which started in 2012, has been heavily criticised for its use of youth-friendly themes and images. It is registered in over 60 countries, and has been subject to a legal challenge in Germany and fines in Brazil, in both cases for its clear targeting of youth. Funded from marketing budgets that run into tens of millions of dollars, billboards, posters, point of sale promotions and 'Be Marlboro' themed events have been ubiquitous, especially in countries with weak tobacco control laws.

But while the intent seems to be saturation coverage of Be Marlboro in countries where PMI can get away with it, the non- 


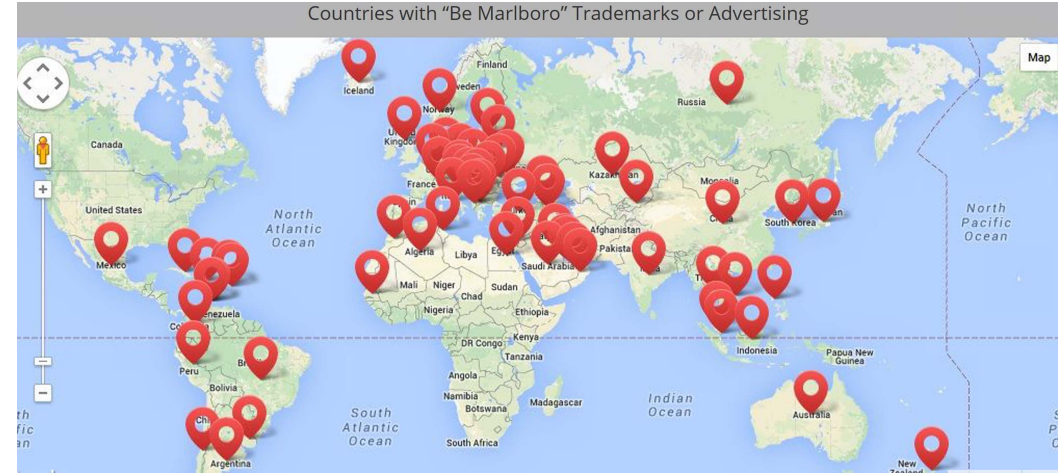

A map showing the countries with Be Marlboro trademarks or advertising. Source: stopmarlboro. org

profit consumer news site Consumerist recently reported that PMI has used copyright muscle to remove a source of scrutiny.

The Campaign for Tobacco Free Kids (CTFK), one of several agencies which have been monitoring the campaign, recently collated several marketing videos and uploaded them to Vimeo, a video-sharing website. The clips were not edited in any way; they were merely made available to demonstrate how Marlboro markets to youth. However, shortly after CTFK notified press outlets of the collection, Vimeo took them down due to a copyright request from PMI's Switzerland office.

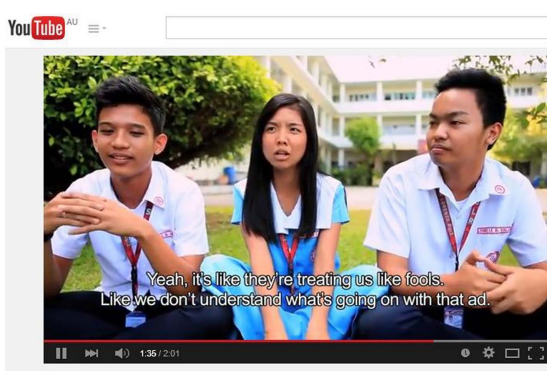

Kids react to "Be Marlboro" Campaign for Tobacco-Free Kids

Filipino teens react to the Be Marlboro campaign. Source: stopmarlboro.org

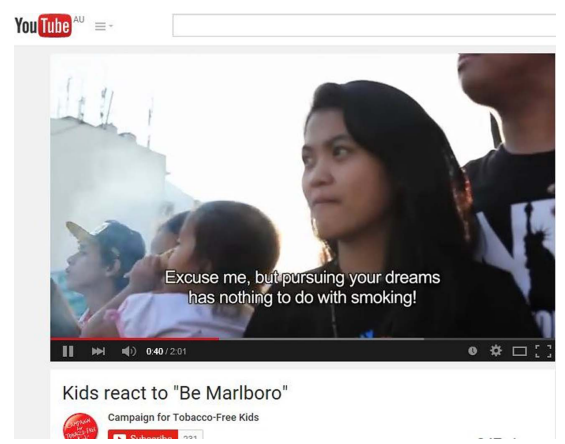

A screenshot from young people talking about the Be Marlboro campaign. Source: stopmarlboro.org
The clips showed the diversity and sophistication of the Be Marlboro campaign, and included events from Slovakia, Moldova, Indonesia and Saudi Arabia (the only clip to show guests actually smoking). The Consumerist report notes that they have contacted PMI for an explanation of why the copyright notice has forced removal of the clips, but (perhaps unsurprisingly) have not received a reply. PMI's reaction to attempts to expose the $\mathrm{Be}$ Marlboro campaign to sunshine brings to mind a cockroach scuttling for a dark corner.

PMI and Marlboro have taken a public relations hammering in recent months: US-based comedian John Oliver's blistering expose on tobacco industry tactics on his show Last Week Tonight in February went viral, helped along by the Twitter hashtag \#JeffWeCan, featuring 'Jeff the Diseased Lung', Oliver's take on an honest mascot for the product to replace its iconic cowboy. 'Jeff' looks set to continue to haunt PMI: in early May it made an appearance at a protest with young people from across the US outside the annual PMI shareholder meeting in New York.

On the CTFK campaign website stopmarlboro.org, teens discussing their impressions of the Be Marlboro campaign are decisive. As one young woman from the Philippines says: "Of course it goes without saying that we're going to pursue our dreams. But don't bring smoking into the picture! Yeah, it's like they're treating us like fools. Like we don't understand what's going on with that ad".

A petition on the stopmarlboro.org website targeting government officials in Argentina, Georgia, India, Indonesia, Moldova, Peru, the Philippines, Senegal and Slovenia at stopmarlboro.org has attracted over 62,000 signatures.

\section{INDIA/WORLD: WORLD BANK DUMPS TOBACCO-SPONSORED EVENT}

The World Bank has withdrawn from the 12th Annual Asia Pacific Tax Forum, an event organised by the Indian Council for Research on International Economic Relations (ICRIER) and International Tax
Tell governments around the world to ban the "Be Marlboro" ad campaign and stop Philip Morris International from marketing its deadly products to kids. 
and Investment Centre (ITIC). ITIC is sponsored by Philip Morris International, Imperial Tobacco, British American Tobacco and Japan Tobacco International. The Forum was scheduled to be held from 5-7 May.

The World Bank's decision came after a challenge by the Indian NGO Institute of Public Health in the Delhi High Court seeking to prevent government officials participating in the conference on the basis that it would violate Article 5.3 of the Framework Convention on Tobacco Control (FCTC). The petition was dismissed due to the fact that the Forum was a general conference on tax.

The president of ITIC, Daniel Witt, had argued that that the Forum would not be a violation of the FCTC because no tobacco-related issues were on the agenda. The Delhi high court ruling suggests this narrow interpretation of the FCTC is held by other key institutions responsible for upholding Article 5.3. This is despite the fact that the guidelines for its implementation state that measures should apply in all branches of government that may have an interest in, or capacity to, affect public health policies with respect to tobacco control.

With tax a key measure of the FCTC (Article 6) and MPOWER package of tobacco control measures ( $\mathrm{R}$ being to raise taxes on tobacco), the World Bank's leadership in withdrawing from the conference provides a powerful counterweight to the misperception that tax policy is unrelated to tobacco control.

\section{UKRAINE: WTO PLAIN PACK CHALLENGE MAY END}

The Kyiv Post has reported that Ukraine's prime minster Arseniy Yatsenuk has expressed doubts about continuing with Ukraine's challenge of Australia's tobacco plain packaging laws through the World Trade Organisation (WTO). Ukraine is one of five countries to have lodged a request for consultation. The others are Honduras, the Dominican Republic, Cuba and Indonesia.

The possible change in the government's stance follows a protest on May 20 by the Coalition for a Smoke Free Ukraine outside the Cabinet of Ministers. Parliamentarian Hanna Hopko, head of the Foreign Affairs Committee, welcomed the Prime Minister's announcement and acknowledged that the issue was damaging Ukraine's international reputation. The protest prompted PM Yatsenuk to instruct Economy Minister Aivaras Abromavisius to assess the implications of Ukraine's action and move quickly to resolve the issue, a step praised in a Kyiv Post editorial.

While the action is welcome, the Ukraine government has a number of key ministers with previous tobacco industry connections or a history of public stances sympathetic to the industry's interests. Assessment of whether to continue the case has been delegated to deputy economic and trade minister Natalia Mykolska, who has been a supporter of the case against Australia. She was targeted in the May 20 protest, together with others who have been tobacco industry supporters.

Others targeted were Svitlana Zaytseva, the head of Ukraine's economy ministry division responsible for cooperation with the WTO; Olena Zerkal, currently deputy minister of foreign affairs for European integration-previously a senior corporate affairs manager at British American Tobacco; and Valeriy Pyatnitskyi, an advisor to the prime minister with a reputation as a lobbyist for tobacco companies.

Ukraine is at a legislative crossroads for tobacco control: the NGO Advocacy Center Life, supported by members of parliament, is pushing for a range of new tobacco control measures including new cigarette pack warnings. The world will be watching to see if Ukraine takes this step away from tobacco industry-supported challenges, thereby improving its international reputation and joining the international community in implementing evidence-based tobacco control measures.

\section{LEBANON: FINANCE MINISTER OPENS TOBACCO FACTORY}

Lebanon's finance minister Ali Hassan Khalil presided over the opening of a new tobacco factory in Beirut in May. The factory will nearly triple cigarette production capacity and will produce a range of international tobacco brands under licence.

In the midst of political disagreements about the national budget, $\mathrm{Mr}$ Khalil praised the factory as a productive addition to the national economy —although no figure was put forward for the additional costs likely to accrue to the health care sector as a result of smoking-related diseases.

Smoking is responsible for nearly $25 \%$ of male deaths and 18\% of female deaths in Lebanon. With smoking prevalence at 34\% (adult males), 21\% (adult females) and nearly $18 \%$ of boys, the country has a long way to go to meet its obligations under the FCTC. Currently it falls short on advertising bans and taxation, health warnings (text warnings only, which cover $40 \%$ of the pack) and taxation, which makes up only $33 \%$ of the retail price, compared to the WHO benchmark of $75 \%$.

No doubt the tobacco industry will be delighted to have such a strong ally in the finance minister, who is clearly untroubled by FCTC provisions that call on governments to protect government policy from tobacco industry interests, prevent incentives for the tobacco industry to establish and run its business, and implement demand reduction measures.

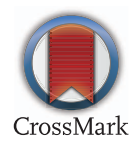

Tob Control 2015;24:316-319.

doi:10.1136/tobaccocontrol-2015-052491 